\title{
THE INFLUENCE OF HUMAN RESOURCE MANAGEMENT PRACTICES ON EMPLOYEE WORK ENGAGEMENT
}

\author{
Adel Ali Yassin ALZYOUD \\ Applied Science University, College of Administrative Sciences, KINGDOM of BAHRAIN \\ e-mail: adel.alzyoud@asu.edu.bh
}

\begin{abstract}
The main objective of this study is to investigate the influence of Human Resources Management (HRM) practices (employee communications, employee development and rewards and recognitions) on employee engagement. Employee engagement has emerged as one of the most important topics in the sphere of human resource management. The aim of this paper is to examine and gain better understanding of the drivers that influence employee engagement in a printing company. Employee communication, employee development, rewards, and recognitions were selected as independent variables. Sample for the study consists of 151 staff from manufacturing. Data were collected with the help of a questionnaire and analyzed using the Statistic Package for Social Science (SPSS) version 23. Throughout the statistical analysis, it is found that there is a significant relationship between the two independent variables with the dependent variable. In conclusion, it is observed that HRM practices have an influence on the employee work engagement. This shows that employers need to develop proper and well-structured HRM policies in attaining high work engagement level among the employees.
\end{abstract}

Keywords: employee communications, employee development and rewards and recognitions, work engagement.

JEL: M1, M10, M12.

\section{1}

\section{Introduction}

In today's economic instability, organization started to look into people as an asset so that organization can utilize their skills, knowledge and abilities to sustain the competitiveness in the industry. This is because employees who are engaged in their work and committed to their organizations give crucial competitive advantages including higher productivity and lower employee turnover (Robert, 2006).

However, according to Gallup Management Journal research done in 2006, only $29 \%$ of the U.S. working population is engaged (loyal and productive), 55\% are not engaged (just putting in time), and $15 \%$ are actively disengaged (unhappy and spreading their discontent) ( "Gallup Study", 2006).

Employees in manufacturing sector are facing bigger challenges nowadays, as the expectations by their employers are increasing. The manufacturing industry in the whole world is facing a rapid transformation.

The introduction of new techniques, technologies, systems, procedures and standards are everyday oc- currences; thus, there is a tremendous need for the employees to keep up with the evolving trend. In order to maintain a high output and efficiency of the employees, organizations are now very much concerned with the psychological state of their workers.

Currently, organizations expect the employees to be proactive, collaborative, take responsibility for their own professional development, and be committed to high-quality performance. In other words, the employers need engaged employees; those who go the extra miles in performing a task, not merely 'doing one's job'.

However, there are claims in Jordan that the level of work engagement in manufacturing companies is very low. The workers are not absorbed in their respective work, and most of them are doing their job for earning (Alrai, 2015).

Therefore, it is apparent that the right practice in HRM may result in better work engagement among the workers. It also suggests that the HRM practice in Jordan does not address the work engagement aspect properly; thus, we require further 
studies and analysis in order to improve the productivity of the manufacturing industry employees.

In this study, the author intends to magnify the research on HRM practices and organizational performance by giving specific focus on work engagement. This is due to the fact that work engagement is one of the least discussed issues in HRM topic.

The lack of studies conducted does not reflect the importance of work engagement in ensuring high productivity among employees. The work engagement plays a pivotal role in enhancing the performance of employees, and the most important factor of ensuring work engagement is the HRM practices.

According to the Conservation of Resource (thereafter labelled as COR) theory (Hobfoll, 1989), resources (in the form of objects, personal characteristics, conditions and energies) are valuable to individuals, as the availability of resources facilitates individuals to accomplish their goals and reduce their job demands (such as time and energy in completing their job).

The COR theory (Hobfoll, 1989) suggests that individual with resources are more capable of gaining more resources and are less inclined to resource loss. The COR theory (Hobfoll, 1989) further suggests that individuals are motivated to protect their resources from loss and will strive to accumulate as many resources as possible.

Consistent with this view, Salanova, Agut and Peiro (2005) proposed that one form of resources at the organizational level are the HRM practices, as these practices are able to assist employees to achieve their work goals effectively and reduce their job demands when executing their task.

When employees are able to implement their jobs with minimal burden, they are more likely to develop a positive attitude at work such as being energetic, dedicated and happy, all of which characterized work engagement (Christian, Garza and Slaughter 2011).

Findings from a recent empirical study by Karatepe (2013) among 110 frontline employees from eight Romanian hotels demonstrated that HRM practices indeed have a positive and significant relationship with work engagement.

\section{$2 \quad$ Literature review}

\subsection{Work engagement}

Work engagement is a business management concept and there are many definitions of this particular construct. According to Schaufeli, et al. (2002, p. 74), work engagement is defined as a "positive, fulfilling, work-related state of mind that is characterized by vigor, dedication and absorption". Vigor refers to a high level of energy and mental resilience at work even when the individual is faced with difficulties. Dedication refers to the involvement, enthusiasm, inspiration, challenge and pride attached to work. Absorption refers to a person's focus and that he/she is happily occupied in work. It was defined by Saks (2006) as a heightened connection between employees and their work, their organization, or the people they work for or with. Schaufeli, et al. (2006) further asserted that work engagement is a persistent, pervasive and positive affective-cognitive state of mind. To measure work engagement, Schaufeli, Bakker and Salanova (2006) introduced the nineitem Utrecht Work Engagement Scale.

In addition, highly engaged employees are more likely to please in terms of their needs and desires that ultimately lead to their satisfaction and retention. Given the significance of work engagement concept in the literature, more studies need to be conducted to further examine this particular construct and understand factors attributed to it.

A number of studies have shown similar positive relationships between HR practices and various measures of firm performance. MacDuffie (1996) found that HR practices were related to productivity and engagement in how manager strategies to develop their workers become engage in work given. In sum, engaged workers possess an energetic and effective drive towards accomplishing their tasks. They also act with confidence and see themselves capable of dealing competently with the challenges that follow from their work.

\subsection{Human resource management}

This study attempts to examine the human resources practices that should be considered by the employer in developing employee engagement in order to cre- 
ate a productive workforce. Guest (2001) mentioned that human resource management is a unitary system of management that attempts to elicit employees' commitment and involvement in line with the purpose and goals of the organization. Human resource is defined as a strategic and coherent approach to the management of an organization's most valued assets, because it is involved in managing people in the organization to achieve the objectives (Dessler, 2005).

HRM is the science and practice that deals with the nature of the employment relationship and all of the decisions, actions and issues that are related to this relationship. Sharma and Khandekar (2006) has developed the model of human resource practices that is supposed to develop the workers ability and work engagement. This showed that human resource practices play an important role of employee engagement. In this study, four dimensions of HRM are used: employee communication, training and development, rewards, and recognitions are studied.

\subsection{Relationship between employee communication and work engagement}

The company should follow an open door policy. There should be both upward and downward communication with the use of appropriate communication channels in the organization. If the employee is given a say in the decision-making and has the right to be heard by his boss then the engagement levels are likely to be high. Good employee communication will help an employee to understand their role and hence contribute to the organization's success (Clampitt, 2005).

It is very clear that engagement begins with employees' clear understanding of what is happening in the organization. Employees should be kept well informed about the changes that affect them.

\subsection{Relationship between employee development, and work engagement}

Training and development is a part of human resource practices tool to improve or obtaining new skills. Training and development focus on changing or improving the knowledge, skill and attitudes of individuals (Werner and DeSimone, 2009). Training prepares employees for a new job, meanwhile development is essential for future assignment.

It is an attempt to improve current or future employee performance by increasing an employee's ability to perform through learning, usually by changing the employee's attitude or increasing his or her skills and knowledge. Training and development was defined as the process by which individuals change their skills, knowledge, attitudes and/or behavior (Robbins and DeCenzo, 1998).

\subsection{Relationship between rewards and recognitions with work engagement}

Reward and recognition for individual employees remains one of the most controversial areas (London and Higgott, 1997), which is a part of compensation package used to motivate, retain as well as attract employees to stay. Recognition is important because it serves as a form of feedback where it helps to inform employees on how well they are performing. However, Seeger (2005) asserted that in order to create ongoing motivation and commitment through employee recognition, reward must be communicated to all employees. Employee reward and recognition programs is a method of motivating employees to change work habits and key behavior for the benefit of the organization.

\section{Methodology}

\subsection{Participants}

This study used a quantitative approach to measure the relationship between HRM practices and employee work engagement. A total of 200 sets of questionnaires were distributed. After the stated time, 151 questionnaires were completed and analyzed.

The study focused on the manufacturing in Bahrain. Out of the total sample size, $74 \%$ were males and $26 \%$ were females. In term of education, $85 \%$ were with bachelor's degree and only 15 master degree. Finally, Majority of the respondents' work experience, $47 \%$ of the sample had over 10 years, $21 \%$ between $6-10$ years and $19 \%$ between $3-5$ years. 


\subsection{Measures}

Work Engagement Scale of Schaufeli, et al. (2002) was used to assess work engagement at the employee level. HRM practices were developed by Uen and Chien (2004), Delery and Doty (1996), and (Robbins and DeCenzo, 1998). Responses are logged on a five-point Likert scale ranging from 1 (strongly disagree) to 5 (strongly agree).

\section{$4 \quad$ Results}

As shown in Table 1, the zero-order correlation between employee communication and work engagement were found to be positively correlated $(\mathrm{r}=$ 0.46). Employee development and work engagement also have a positive relationship $(\mathrm{r}=0.37)$.

Table 1. The descriptive statistics of the variables $(n=151)$

(Source: own elaboration)

\begin{tabular}{|l|c|c|c|c|c|c|c|}
\hline \multicolumn{1}{|c|}{ Variable } & $\mathrm{M}$ & $\mathrm{SD}$ & $\alpha$ & 1 & 2 & 3 & 4 \\
\hline Employee communication & 3.64 & 0.49 & 0.76 & - & & & \\
\hline Employee Development & 3.87 & 0.61 & 0.80 & 0.02 & - & & \\
\hline Rewards and recognitions & 3.91 & 0.52 & 0.83 & $0.36^{* *}$ & $0.40^{* *}$ & - & \\
\hline Work engagement & 3.74 & 0.48 & 0.72 & $0.46^{* *}$ & $0.37 * *$ & $0.56^{* *}$ & - \\
\hline
\end{tabular}

Similarly, rewards and recognitions and work engagement were found to be positively correlated $(\mathrm{r}=$ 0.56). Cronbach Alpha reliability test was conducted for all the measures. Reliabilities were tested and they fell between 0.72 and 0.83 , which is satisfactory for a study that is exploratory in nature (Nunnally, 1978). The mean and standard deviation (SD) values are also given in the Table 1, the employee communication $(M=3.64$; $S D=0.49)$, rewards and recognitions, work engagement $(\mathrm{M}=3.74 ; \mathrm{SD}=0.48)$ and employee development $(\mathrm{M}=3.87 ; \mathrm{SD}=0.61)$ were found to be relatively high.
Regression analysis was carried out with the help of SPSS 23 to investigate the impact of the three dimensions of Human Resource Practices and work engagement. Regression model in regression Table 2 confirms that in total, all the three dimensions of human resource (employee communications, employee development and rewards and recognitions) stimulates work engagement $\left(R^{2}=0.42 ; F=36.50\right.$; $\mathrm{P}<0.01)$. In other words, employee communications, employee development and rewards and recognitions altogether explained $42 \%$ of total variance of work engagement.

Table 2. Regression results (Source: own elaboration)

\begin{tabular}{|l|c|c|c|c|c|}
\hline \multicolumn{1}{|c|}{ Model } & \multicolumn{2}{c|}{$\begin{array}{c}\text { Unstandardized } \\
\text { Coefficients }\end{array}$} & \multicolumn{2}{c|}{$\begin{array}{c}\text { Standardized } \\
\text { Coefficients }\end{array}$} & Significant \\
\hline & B & Std. Error & Beta & & \\
\hline (Constant) & 0.61 & 0.31 & - & 2.01 & $0.04 * *$ \\
\hline Employee communication & 0.32 & 0.07 & 0.32 & 4.78 & $0.00 * *$ \\
\hline Employee development & 0.17 & 0.05 & 0.22 & 3.16 & $0.00 * *$ \\
\hline Rewards and recognitions & 0.33 & 0.06 & 0.36 & 4.82 & $0.00 * *$ \\
\hline$* * \mathrm{P}<0.01 ; \mathrm{R}^{2}=0.42 ; \mathrm{F}=36.50$ & & & & \\
\hline
\end{tabular}


Moreover, standardized coefficient and $\mathrm{T}$ values also depict positive and significant impact of employee communications on work engagement $(\beta=0.32 ; \mathrm{t}=$ 4.78); employee development on work engagement $(\beta=0.22 ; \mathrm{t}=3.16)$; rewards and recognitions on work engagement $(\beta=0.36 ; \mathrm{t}=4.82)$. Hence, the hypotheses $\mathrm{H} 1, \mathrm{H} 2$ and $\mathrm{H} 3$ were supported.

\section{Discussion}

In this study, we sought to examine the influences of HRM practices on work engagement. Our statistical results provided good support for the effects of HRM practices on work engagement. Attracting and retaining key employees is continually a challenge; on the other hand, it has become more challenging due to the competition for skillful employees. The employees feel that effective HR practices (employee communications, employee development and rewards and recognitions) have a direct and positive relationship with an employee who is engaged.

The organizations that fruitfully attract and engage key employees offer dynamic environment. The employee communications, employee development and rewards and recognitions given by manufacturing sector to its employees is a dynamic policy that helps organizational achievement. The employees hold the opinion that rewards and recognitions contribute to improving an employee's engagement toward the organization. The results indicate that manufacturing is very capable and successful in employee engagement. It is also providing communications that is helping in engaging the employees at all levels.

Development is a process of developing expertise in employees for the purpose of better performance. Development is vital in improving the success and in engaging the key employees. Workforces are dedicated to the employer if the employer is committed and supportive for their long term job development. Workforces come to the organization with certain necessities, desires and skills and expect that they would be given an environment where they can utilize and enhance their abilities and satisfy many of their needs.

Employees feel that communications, rewards and recognitions and development needs of workforce are not being properly taken care of. A study conducted by (Suan and Nasurdin, 2016) whereby workers who feel they are listened to, supported and recognized for their contributions are likely to be more engaged, and therefore, they tend to stay in the same organization for a long run.

The researcher thus recommends future longitudinal studies and multilevel analytic approaches to differentiate and disaggregate variance at the individual, group, and organizational level can help map the strength of the direct and indirect relationships proposed. We recommend that it would be useful to conduct additional theory-based research to determine how the four engagement-focused HR practices interact.

Hopefully, our model will stimulate and guide future research and promote a greater understanding of the importance of establishing HRM practices and climates that are strategically focused on employee engagement.

\section{Conclusion}

The current study also contributes practically by concluding that communications, employee development and rewards and recognitions definitely provides a strong base for dynamic organizations to manage the creative culture that can promote their abilities and competency as well as other strategic priorities to gain a competitive advantage. Findings of this study show that employee communications, employee development and rewards and recognitions is pivotal for engaging among employees. And managers should provide communications, development and rewards and recognitions to the employees in order to increase the level of employee engagement.

\section{$7 \quad$ References}

[1] Choo Ling Suan, Aizzat Mohd Nasurdin, 2016. Supervisor Support and Work Engagement of Hotel Employees in Malaysia: Is it Different for Men and Women? Gender in Management: An International Journal, 31(1), pp.2-18, https://doi.org/10.1108/GM-11-2014-0105. 
[2] Christian, M.S., Garza, A.S., Slaughter, J.E., 2011. Work Engagement: A Quantitative Review a Test of Its Relations with Task and Contextual Performance. Personnel Psychology, 64(1), pp.89-136. http://dx.doi.org/10.1111/ j.1744-6570.2010.01203.x.

[3] Clampitt, P.G., 2005. Communicating for Managerial Effectiveness. Sage. CA.

[4] Delery, J.E., Doty, D.H., 1996. Modes of Theorizing in Strategic Human Resource Management: Tests of Universalistic, Contingency, and Configurational Performance Predictions. Academy of Management Journal, 39(4), pp.802-835.

[5] Dessler, G., 2005. Human Resource Management, 10th ed., Pearson Education, Inc., Upper Saddle River.

[6] Guest, D., 2001. Human Resource Management and Performance: A Review and Research Agenda. International Journal of Human Resource Management, Vol. 8(3), pp.263-276.

[7] Hobfoll, S.E., 1989. Conservation of Resources: A New Attempt at Conceptualizing Stress. American Psychologist, 44, pp.513-524. https://doi.org/10.1037/0003-066X.44.3.513.

[8] Karatepe, O.M., 2013. High-Performance Work Practices and Hotel Employee Performance: The Mediation of Work Engagement. International Journal of Hospitality Management, Vol. 32 March, pp.132-140.

[9] London, H., Higgot, K., 1997. An Employee Reward and Recognition. The TQM Magazine. 9(5), pp. pp.328-335.

[10] MacDuffie J.P, 1996. Human Resource Bundles and Manufacturing Performance: Organizational Logic and Flexible Production Systems in World Auto Industry. Ind. Labour Relat. Review, 48(2), pp.197-221.

[11] Nunnally, J.C., 1978. Psychometric Theory. 2nd ed., McGraw-Hill, New York, NY.

[12] Robbins, S.P., DeCenzo, D.A., 1998. Fundamentals of Management: Essential Concepts and
Applications. Upper Saddle River, N.J: Prentice Hall.

[13] Robert, M., 2006. Stress in the Work Place. (1st Edition). New Jersy. Pearson Publishers.

[14] Saks, A.M., 2006. Antecedents and Consequences of Employee Engagement. Journal of Managerial Psychology, 21(7), pp.600-619. http://dx.doi.org/10.1108/02683940610690169.

[15] Salanova, M., Agut, S., Peiró, J.M., 2005. Linking Organizational Resources and Work Engagement to Employee Performance and Customer Loyalty: The Mediation of Service Climate. Journal of Applied Psychology, Vol. 90, pp.1217-1227.

[16] Schaufeli, Bakker, A.B., Salanova, M., 2006. The Measurement of Work Engagement With a Short Questionnaire a Cross-National Study. Educational and Psychological Measurement, 66(4), pp.701-716. http://dx.doi.org/10.1177/ 0013164405282471.

[17] Schaufeli, W.B., Martínez, I.M., Pinto, A.M., Salanova, M., Bakker, A.B., 2002. Burnout and Engagement in University Students. Journal of Cross-Cultural Psychology, 33(5), pp.464-481. http://dx.doi.org/10.1177/002202210203300500 3.

[18] Seeger, 2005. Communicating Employee Recognition at MDOT. Strategic HR Review, Vol. 4, Issue 6, pp.12-13, https://doi.org/ $10.1108 / 14754390580000829$.

[19] Sharma, A., Khandekar, A., 2006. Strategic Human Resource Management: An Indian Perspective. New Delhi: Sage Publication.

[20] Uen, J.F., Chien, S.H., 2004. Compensation Structure, Perceived Equity and Individual Performance of R\&D Professionals. Journal of American Academy of Business, 4(1/2), pp.401405 .

[21] Werner, J.M., DeSimone, R.L., 2009. Human Resource Development. Mason, USA: SouthWestern, Cengage Learning. 